\title{
Biotech bailout?
}

\section{A rescue of some sort will be needed to save a large subset of the US biotechnology industry.}

\section{T} he mood at this year's Biotechnology Industry Organization (BIO) International Convention, held 18-21 May in Atlanta, was tinged with concern. Characterizing the economic outlook as "bleak" in his state-of-the-industry address, Jim Greenwood, BIO's CEO, provided some chilling statistics about the financial health of the US biotechnology industry: $40 \%$ of the biotechnology companies publicly traded in the United States have less than 1 year of cash in their coffers, and approximately 30\% started 2009 with less than 6 months of funds on hand.

And new money is hard to come by. Venture capital investment in the industry across the globe is down almost 50\% in 2009 compared with the same period in 2008. For some companies, even preexisting investments are hard to hold on to. Several companies, including Avigen, Trimeris and Penwest Pharmaceuticals, were forced to postpone plans for research and development (R\&D) and/or mergers, or even to completely liquidate, so that existing equity could be converted to cash and returned to private investors. With many biotechnology companies trading on public indices for less than the value of cash in their accounts and lacking products in the mature end of the development pipeline, this sort of 'raiding' activity is likely to continue.

Funding from sources outside the venture capital arena is also scarce. Although big pharmaceutical companies have in the past rescued cashpoor biotechnology firms with promising products in the pipeline, it is not reasonable to expect these companies to rescue the biotechnology industry as a whole. Now in the midst of a wave of mergers and acquisitions in their own industry, large pharmaceutical companies are occupied with restructuring and streamlining their own R\&D agendas. By the time many are in a position to pursue the bureaucracy-intensive process of identifying and acquiring biotechnology companies with promising mature products able to easily fit into relevant $\mathrm{R} \& \mathrm{D}$ portfolios, it may be too late (http://www.nature.com/nbt/journal/v27/n2/full/nbt0209-101. $\mathrm{html}$ ). With almost no biotechnology initial public offerings on the 2009 calendar, public equity funding is unlikely to come to the rescue.

Fortunately for the subsector of the biotechnology industry focused on innovative methods to produce biofuels, and thanks to a 2007 US law that set mandates for oil refineries to blend more biofuels into their product, some big oil companies have taken an interest in biofuel startups. BP, Royal Dutch Shell and Chevron have all ramped up their funding of small biofuel companies. Whether these nascent partnership efforts will be enough to support a large portion of the biofuel subsector remains to be seen.

What about the US government, which recently put up funds to bail out the US finance and auto industries when they were facing imminent annihilation? BIO, recognizing the immediacy of the need for funds, has asked the US Congress to pass measures to suspend or decrease capital gains on funds invested in biotechnology and to permit biotechnology companies to convert net operating losses into tax refunds that can be used to fund future research. Whether Congress will grant this request remains to be seen. A few states, including Georgia (the host of the 2009 BIO convention), have offered some additional financial incentives and support for biotechnology investors and companies. However, these efforts have been spotty at best.

In contrast, other national governments have already provided cash infusions to local biotechnology companies. The UK government recently approved a measure providing US $\$ 1.1$ billion in the form of a new Strategic Investment Fund to support commercial science and technology operations. Norway and India have also offered funds to biotechnology companies operating within their borders.

The fact that the US biotechnology industry has not lobbied for an outright handout of government cash is admirable. However, if no assistance at all is provided, a large subset of US biotechnology companies will certainly go under-and soon. The short-term and longterm consequences could be dire. The immediate loss of thousands of biotechnology jobs will leave a large pool of scientists searching for employment. With public funding of academic research already tight, and large pharmaceutical companies laying off workers as a result of mergers and acquisitions, the job outlook for these people will be discouraging, to say the least.

In the longer term, the biotechnology pipelines from which big pharmaceutical companies have so frequently plucked promising compounds will run slower, if not run dry. The dissolution of promising young companies working on biofuels could, to some extent, slow the innovation needed to solve environmental problems increasingly recognized as urgent by governments around the globe.

Making this situation all the more frustrating is the fact that, for the first time in the history of the industry, US biotechnology as a whole ran a profit in 2008. In 2008, General Motors alone lost US $\$ 30.9$ billion. In addition, in contrast to the US auto industry - which has for years lagged far behind European and Asian automakers in terms of practical innovation—-the US biotechnology industry virtually runs on innovation.

Big pharmaceutical companies, big oil companies, private investors and the US government are all coping with their own financial woes and budget shortfalls. Whether any of these groups will be willing and able to rescue the biotechnology companies that are worth saving is unclear. What is clear are the dire short-term and long-term consequences of large-scale devastation of the biotechnology industry. The clock is ticking. 